\title{
Firm Bankruptcy Probability and Causes: An Integrated Study
}

\author{
Oliver Lukason ${ }^{1} \&$ Richard C. Hoffman ${ }^{2}$ \\ ${ }^{1}$ Faculty of Economics and Business Administration, Tartu University, Tartu, Estonia \\ ${ }^{2}$ Franklin P. Perdue School of Business, Salisbury University, Salisbury, USA \\ Correspondence: Oliver Lukason, Faculty of Economics and Business Administration, Tartu University, Narva \\ Road 4, 51009 Tartu, Estonia. E-mail: oliver.lukason@ut.ee
}

Received: June 26, 2014

Accepted: September 9, 2014

Online Published: October 22, 2014

doi:10.5539/ijbm.v9n11p80

URL: http://dx.doi.org/10.5539/ijbm.v9n11p80

\begin{abstract}
The objective of the study is to examine the impact of both the number and types of causes of business failure on the failure risk as indicated by values of bankruptcy scores during the process of business decline. Causes of bankruptcy were obtained from court judgments for 70 Estonian manufacturing firms and classified into two taxonomies-the number of causes and the different types of causes of failure such as internal (different management deficiencies) or from factors external to the firm. Bankruptcy scores for the first and second pre-bankruptcy years were calculated using both Ohlson's model and a local (Grünberg's) bankruptcy prediction model. Independent samples median tests were applied to examine, whether different causes are associated with different failure risk. Findings indicate that multiple causes lead to a significantly higher bankruptcy risk than a single cause for the year prior to the declaration of bankruptcy. On the contrary, no significant effect of different types of failure causes was found on the risk of failure. Implications of the results for research and practice are discussed.
\end{abstract}

Keywords: firm failure, failure causes, bankruptcy models, failure process, manufacturing firms

\section{Introduction}

Much of the extensive research on firm failure has focused on failure prediction (e.g., reviews by Dimitras, Zanakis, \& Zopounidis, 1996; Altman \& Narayanan, 1997), with other domains such as failure causes and processes remaining relatively under investigated. Previous empirical studies have mostly used the narrow definitions of business failure (e.g., see Cochran, 1981), namely bankruptcy, in part, because it facilitates data collection. Hundreds of bankruptcy prediction studies conducted so far focus on various sectors with manufacturing firms being among the most prominent sectors researched (e.g. Dimitras et al., 1996). Recently, most of the innovation in prediction studies has been directed at introducing novel methods for calculating bankruptcy; however, this has not resulted in improved accuracy in predicting business failure (Constand \& Yazdipour, 2011). Despite the growing literature on business failure prediction, only a few comprehensive theoretical (e.g. Mellahi \& Wilkinson, 2004) and empirical (e.g. Baldwin et al., 1997) studies have focused on the causes of business failure. There is an even smaller stream of research being conducted on failure processes (e.g. Argenti, 1976; D'Aveni, 1989; Ooghe \& de Prijcker, 2008) that attempt to outline the different stages leading to firm failure. In an extensive review of the literature Trahms, Ndofor, \& Sirmon (2013) have called for studies integrating firms' resource use and decline. Moreover, these authors call for using more complex indicators than merely changes in profitability for measuring decline. The few available studies of this type (see e.g. Hambrick \& D'Aveni, 1988; Moulton, Thomas, \& Pruett, 1996) do not apply complex indicators of decline or the whole spectrum of possible causes of failure. Thus, this current study aims to be the first to relate the actual causes of failure to a firm's failure risk and its actual onset as reflected through its bankruptcy scores prior to failure. The rest of the paper is structured as follows. A review of the extant literature is provided to aid in developing the research hypotheses for the study. This section is followed by a description of the research methods employed to collect data on the financial and non-financial variables for this study. Then the methods of data analysis are also described. The findings with discussion are then presented along with implications for future research and practice.

\section{Review of Literature and Hypotheses}

Identifying the spectrum of studies on the causes of business failure depends on the definition of the term 
"failure". The concept of "failure" can vary from the narrow definition of bankruptcy or permanent insolvency to simply non-achievement of goals (Cochran, 1981; Pretorius, 2009). It should also be noted that not all failed firms are discontinued and vice versa (Fredland \& Morris, 1976). Thus, the choice of "failure" definition is vital for identifying the relevant literature. In this paper we focus on the narrowest definition of business failure, namely, bankruptcy.

\subsection{Bankruptcy as Failure}

Normally, a firm does not go bankrupt instantaneously, but goes through a failure process which varies considerably in length. It has been shown that large corporate failures are often characterized by a very lengthy failure process; whereas, for small to medium enterprises (SMEs), it can emerge quickly (e.g., Argenti, 1976; Hambrick \& D'Aveni, 1988; Laitinen, 1991). Bankruptcy has also been viewed as the final stage of the decline process. According to Weitzel \& Jonsson (1989), the firm decline process consists of five stages and successful reorganization/turnaround is not possible only at the very last stage. Still, the failure process can vary widely depending on the age, industry, size, and national location for similar firms (Hambrick \& D'Aveni, 1988; Laitinen, 1991; Ooghe \& de Prijcker, 2008; Laitinen \& Lukason, 2014). This study assumes that some failure processes will be more gradual than others, and we wish to take this process into account in examining the relationship between failure causes and the onset of bankruptcy.

Most theoretical studies do not define how to measure decline or the firm's health during the failure process (e.g. Argenti, 1976; Weitzel \& Jonsson, 1989), but they suggest that various indicators could fit that purpose. Some previous studies on corporate turnarounds (firms that start to fail but then reverse the decline; e.g. Barker \& Duhaime, 1997) purposefully use single indicators (e.g. different profitability measures) of declining performance. Still, in the context of such a complex phenomenon as business failure, this would appear to be a too narrow approach (see e.g. Trahms et al., 2013). Therefore, in most failure prediction studies, a firm's health (or failure risk) has been traditionally determined through the use of bankruptcy models, which either provide a score (e.g. multiple discriminant analysis models) or conditional probability (e.g. logit models) of bankruptcy. Given the number of bankruptcy models, a wide variation of predictors has been applied (see Dimitras et al., 1996). Bankruptcy models may also be localized in their predictive ability because of the nature of the business and the economy in which the firm is located. Thus, when using bankruptcy scores, more than one model should be applied in order to obtain reliable results (Ooghe \& Balcaen, 2007). For the reasons given above, this study uses bankruptcy as the indicator of business failure.

\subsection{Reasons for Business Failure}

Some studies (e.g. Hall, 1992) have sought to capture only the most important reason for business failure. Yet, such an approach is contrary to the assumption that there are usually a multitude of reasons for business failure (Dubrovski, 2009). While the evidence about what constitutes the most frequent reason for business failure remains mixed, various empirical studies (e.g. Baldwin et al., 1997) tend to support the theoretical assumption (e.g. Mellahi \& Wilkinson, 2004) that firm failure is rarely caused by only one cause or source.

Since the literature does not specifically outline, how different causes of firm failure contribute to firm decline (as reflected by bankruptcy score value and its change), research hypotheses must be synthesized based on available studies. As noted previously, the firm decline process can vary in length and time. Moreover, it is also important to note that changes in financial ratio values are important predictors at different stages of the firm failure process (Laitinen, 1993). Past research has demonstrated that, in extreme cases, bankruptcy can emerge from a single cause, for instance, because of some severe management mistake or external shock (e.g. Mellahi \& Wilkinson, 2004; Crutzen, 2009; Lukason, 2013). Studies have also established that a certain proportion of failing firms follow a very quick failure process such as the sudden decliners described by D'Aveni (1989) and the acute failure firms in the Laitinen (1991) study. Thus, due to its rapid emergence, bankruptcy cannot be forecasted in these cases by using the firms' annual reports. Previous studies point to the fact that such firms might have a bankruptcy score value similar to that of a healthy firm just before insolvency emerges, and therefore, the score's pre-insolvency change is also not very large. In cases where the failure process starts earlier (i.e. lingerers and gradual decliners), many failure causes are often identified (D'Aveni, 1989) and may be detected before the onset of bankruptcy in the pre-bankruptcy years. 
Table 1. Causes of business failure as indicators of the onset of business decline

\begin{tabular}{|c|c|c|c|}
\hline Causes of failure / time before failure & $\mathrm{t}-2$ & $\mathrm{t}-1$ & $\mathrm{t}$ \\
\hline Single cause (internal or external) & No indication of failure & No indication of failure & \multirow{2}{*}{$\begin{array}{l}\text { Onset of business } \\
\text { failure } \\
\text { (bankruptcy) }\end{array}$} \\
\hline Multiple causes (of any type) & No indication of failure & Definite indication of failure & \\
\hline
\end{tabular}

Thus, as depicted in Table 1, when a (small or medium-sized) firm has become insolvent at time $t$ due to a single failure cause (e.g., an external shock or severe mistake by management), the firm's bankruptcy is not likely to be indicated by the financial information in the firm's last annual report at $t-1$. In turn, when bankruptcy is found to be the result of multiple causes (regardless of their type), the causes tend to accumulate over a longer time period; therefore, the decline starts earlier and can be more easily identified in the firms' financial reports prior to the year of the actual onset of bankruptcy. This leads us to the following hypotheses regarding the relationship between the number of failure causes and bankruptcy scores serving as indicators of actual firm failure:

Hypothesis 1a: Bankruptcy score values for firms failing due to a single cause are significantly different from the values of those firms failing from multiple causes at the end of pre-bankruptcy year.

Hypothesis 1b: When business failure is the result of a single cause, the bankruptcy scorevalues at the end of pre-bankruptcy year do not indicate an impending failure.

Hypothesis 1c: When business failure is the result of multiple causes, the bankruptcy score values at the end of pre-bankruptcy year indicate an impending failure.

Another important gap in the literature is that it does not provide an assessment of the impact that different types of causes of business failure might have on firm decline. Various taxonomies have been applied to classify the causes of business failures, and with a few exceptions, many of these other taxonomies (e.g. Hall, 1992; Gaskill, Manning, \& van Auken, 1993; Blazy \& Chopard, 2010) appear to represent the type of data just as it was collected. At least theoretically (Boyle \& Desai, 1991; van Witteloostuijn, 1998; Mellahi \& Wilkinson, 2004), the taxonomy describing internal and external causes of failure seems to be dominant in the literature. Drawing on the aforementioned studies, we define internal causes of failure as those that are within management's control such as marketing, production, financial, human resources, etc. decisions/actions that are made by the firm's management; these can either be operational (short term) or strategic (long term) in nature. Moreover, as van Witteloostuijn (1998) observed internal causes may be either overly active or overly passive responses on the part of managers. We do not distinguish between active/passive managerial responses in this study.

External causes of failure are those that stem from outside of the firm and are not in management's control (see Boyle \& Desai, 1991), but they may require a response from management due to changes: in the broader environment of the firm (e.g. economic downturns, or changes in demographics, technology or regulations), from within the industry (e.g. competition, firm entry/exit) as well as uncontrollable changes affecting the firm e.g. illness or death of key personnel, a sudden catastrophe such as a fire or product liability suit. Again this study will not attempt to distinguish between the different types of external causes.

Although we could not find any studies that have systematically evaluated the comparative impact of internal versus external causes of business failures, a couple of studies have suggested that, based on management responses, it appears that business failures were largely caused by internal factors (e.g. Hall, 1992; Gaskill et al., 1993; Blazy \& Chopard, 2012) as opposed to external ones. Similar impacts due to internal causes have been found in some corporate turnaround studies, wherein, internal factors were found to be the primary cause of performance declines (e.g. Bibeault, 1982). Still, there are also examples of opposite results, for instance Baldwin et al. (1997) found internal and external causes to be almost equally represented. Thus, both types of causes are likely to be important in different situations. In some turnaround studies it has been found, that retrenchment response and performance are not impacted by turnaround cause, either internal or external (e.g. Robbins \& Pearce II, 1992). Thus, we deduce that firms witnessing multiple failure causes, decline in a similar way regardless the types of causes. Given statement considers only cases with multiple failure causes, because the first set of hypotheses already covers the comparison of failure cases caused by a single versus multiple reasons. Otherwise, the results of the second set of hypotheses would be directly dependent of the share of cases where failure emerged because of only one reason.

Thus, in the second set of hypotheses, we concentrate on comparing the effects of reasons from a single or multiple environments on failure. We propose, that on an average, firms experiencing reasons from only one 
environment - multiple internal reasons (e.g., poor production management and lack of marketing skills) or multiple external reasons (e.g., new entrants to the market and rise in production input prices) - experience similar decline when compared with firms failing due to reasons from multiple types of environments (poor cost controls and sudden decline in demand; increased competition and poor strategic planning). We propose that in both groups outlined, firms are gradual decliners, and thus their bankruptcy scores at $t-1$ already point to forthcoming problems. Summarizing the above given arguments, we propose the following hypotheses.

Hypothesis 2a: Bankruptcy score values at the end of pre-bankruptcy year are not significantly different between cases where bankruptcy occurred due to a single type of causes and cases where bankruptcy occurred due to different types of causes.

Hypothesis 2b: When business failure is the result of a single type of causes (either internal or external), the bankruptcy score values at the end of pre-bankruptcy year indicate an impending failure.

Hypothesis 2c: When business failure is the result of both types of causes (internal and external), the bankruptcy score values at the end of pre-bankruptcy year indicate an impending failure.

\section{Data \& Methodology}

\subsection{Industry}

Data for this study came from 70 Estonian manufacturing firms (SMEs) that failed between the years of 2002 to 2009 and was obtained from the Estonian Centre of Registers and Information Systems. In the case of business failure, there are industry effects; firms in different sectors go through different failure processes (see Laitinen, 1991), namely they are affected by different causes of failure, and their financial health deteriorates differently. As a result, this study examines firms in one sector, the Estonian manufacturing sector (NACE code C). Manufacturing is the largest sector in Estonia in terms of the number of workers employed, and it is the second largest in terms of sales/turnover. Moreover, the manufacturing sector was less affected by the recent economic recession in Estonia (year 2009 having GDP drop of 15\% and in 2010 a small increase compared with the previous year) than the retail and construction sectors. Consequently, the causes of failure in the manufacturing sector are less time specific. In addition, the majority of the most frequently used bankruptcy models are based on data from manufacturing firms, thus, facilitating the use of appropriate measures of failure in this sector. During the period 1999-2012, the number of bankruptcies in the Estonian manufacturing sector has varied from 52 (year 2012) to 157 (year 2009), the average for the period being 82 bankruptcies per year. It should be noted, however, that there were twice as many insolvencies in this sector during the peak recession years of 2009 and 2010 (157 and 134 bankruptcies respectively). Furthermore, manufacturing firms can often face a larger variety of failure causes due to their more sophisticated operational processes as compared with commercial and service firms. Thus, the failure taxonomy used is based on a wider set of specific reasons than those derived from other sectors.

\subsection{The Causes of Failure}

The causes of failure are obtained from court judgments because the Estonian Bankruptcy Act obliges the trustee to identify them in their reports to the court. The list of court judgments was obtained from the Estonian Ministry of Justice's Data System of Courts (judgments since year 2006) and Database of Court Statistics and Decisions (judgments up to year 2005). The court judgment includes information about the firm's register code that allows one to connect the cause of failure with the firm's financial reports. Each court judgment includes a summary of failure reasons in the form of a list as well as a longer description of the failure process. The use of trustee opinion has been a common option in previous studies (e.g. Hall, 1992; Baldwin et al., 1997), mainly because parties from within the firm can have a narrow, faulty or contradictory perceptions when identifying the reasons for their firms' failure (Beaver, 2003). Using trustees to identify the causes for failure is preferred for two reasons. First, they are independent assessors with no stake in the failed firms. Secondly, they are expected to have sufficient skills to assess the causes of failure, as they have to pass an exam in Estonia, which also focuses on accounting and business planning knowledge. Additional reliability of the trustees' opinions has not been independently verified as they are obliged to present correct information to the court. Moreover, as trustees have sometimes worked several years with a specific bankruptcy case, it is highly likely that they possess sufficient knowledge about the actual causes of collapse. Still, it should be acknowledged that different trustees can have different approaches for classifying the causes of business failure, which could have some effect on the results, especially when a highly detailed taxonomy of failure causes is used.

Thus, in order for the causes of failure to be comparable, relatively universal taxonomies should be applied. As indicated earlier, we have selected the internal/external taxonomy for use in this study because it has been widely 
accepted in the literature (e.g. Boyle \& Desai, 1991; Baldwin et al., 1997), and has some face validity. Furthermore, its use facilitates comparisons of the results of this study with prior research. Given that prior studies have classified specific reasons under the external and internal categories, we have used these as guidelines to help classify the reasons recorded by the trustees for our sample firms. The list of different reasons extracted from the judgments is provided in Appendix A. There are 70 cases in our analysis that provided a total of 142 reasons for failure (among them 61 unique reasons); therefore, the mean and median number of reasons per judgment is two.

To operationalize the taxonomy, the dataset was partitioned into two groups. Group 1 referred to the number of failure causes: a) judgments that describe only one failure reason was labelled Group 1.1, b) judgments that have more than one cause of failure was labelled Group 1.2. Group 2 represents the different types of causes of business failure, external or internal: a) failures resulting from a single type of cause for failure (either internal or external) was labelled Group 2.1, b) failures caused by both internal and external factors were labelled Group 2.2. As noted earlier, for Group 2 only those cases are applied where failure is caused by multiple reasons, thus reducing the dataset to 54 cases.

\subsection{Financial Data and Bankruptcy Scores}

The financial data of our sample firms were obtained from the Estonian Centre of Registers and Information Systems, which collects annual reports from firms. For all firms in the analysis, bankruptcy scores were calculated for the first (i.e. $t-1$ ) and second pre-bankruptcy years (i.e. $t$-2). It should be clarified, that the application of logit bankruptcy models results in conditional probability, but in current study we shortly refer to it as "score". Then, the change in score value was calculated as $\left(\right.$ Score $_{t-1}-$ Score $\left._{t-2}\right)$, where Score $t_{t-1}$ refers to bankruptcy score value in the year previous to the bankruptcy year and Score $\mathrm{t}_{-2}$ two years previous to the bankruptcy year respectively. The change in the score is not calculated as a percentage, as the values are already in the range $[0,1]$. The change between only the two latest pre-bankruptcy years is calculated, because the literature indicates that the majority of the drop in financial performance occurs during that period (e.g. D'Aveni, 1989; Laitinen, 1991; Laitinen, 1993). Still, we also calculated the bankruptcy scores for period $t$-3, but as the median $t-3$ score was not significantly different from that of period $t-2$ (which also reflected a healthy firm using the Ohlson score - see Table 2 and Table 3), one may conclude that the majority of firm failure occurs between $t-1$ and $t-2$. Also, relevant studies (e.g. D'Aveni, 1989; Laitinen, 1991) have applied $t-1$ as the last period in their analyses, as it is the last period from which financial reporting is available. As the use of bankruptcy scores requires the presence of three years data, the dataset of bankrupt manufacturing firms was constrained to those firms providing three annual reports in the database. It must also be noted, that the majority of firms in the analysis went bankrupt during the last quarter, thus, the time between the declaration of insolvency and the last financial information is quite homogenous in our dataset.

Two types of bankruptcy models are employed here to determine business failure. The first is Ohlson's (1980) bankruptcy model (see Appendix B), which is the classic tool for studying firm failure or survival. In this study a decrease in the firms' financial health is measured using the change in the Ohlson (1980) bankruptcy score. The score is calculated by fitting the value $O$ calculated based on given variables and coefficients to following equation: $1 /\left(1+e^{-0}\right)$. Ohlson (1980) was the first one to apply logistic regression analysis in bankruptcy prediction. His study included three models, from which one predicted bankruptcy within one year, the other within two years, and the third within one or two years prior to failure. Ohlson's third model is applied, which is designed to account for data from both the first and second pre-bankruptcy years. Moreover, the coefficients in Ohlson's third model follow the theoretical expectations regarding variable performance in a situation of forthcoming insolvency.

In order to prove the validity of the results using the Ohlson (1980) model, the analysis should also be conducted with an additional bankruptcy model. For that purpose, an Estonian-specific model developed by Grünberg and Lukason (2014) and based on manufacturing firms was selected as the second bankruptcy measure to assess business failure (see Appendix C; later referred to as Grünberg's model). The score of Grünberg's model is calculated identically to Ohslon's score, namely by fitting the value $G$ calculated based on given variables and coefficients to following equation: $1 /\left(1+e^{-\mathrm{G}}\right)$. To summarize the choice of bankruptcy models, the Ohlson (1980) model was chosen mostly because of its citation in previous studies, while the Grünberg's model was selected because of its relevance to the local context.

\subsection{Application of Statistical Test}

The tests of the hypotheses 1a and 2a were conducted with a non-parametric Independent Samples Median Test (ISMT). A non-parametric test was used because the datasets are small and the normality assumption in the data 
is violated. The ISMT tests if the median of one sample differs from that of other comparative samples. Also, due to the small size of the dataset we compare ISMT p-values to a 0.05 level when validating the hypotheses. The results for all other hypotheses $(1 \mathrm{~b}, 1 \mathrm{c}, 2 \mathrm{~b}, 2 \mathrm{c})$ are obtained by using median bankruptcy score values, specifically whether they are over or under the cut-off point of 0.5 . Firm's having values below 0.5 are more likely to survive and vice versa.

\section{Results}

The tests of the hypotheses were conducted in two stages. The first stage examines hypothesis 1a to 1c by applying both bankruptcy models, followed by the second stage of analysis testing hypotheses $2 \mathrm{a}$ to $2 \mathrm{c}$ by also applying both bankruptcy models. The results of all the hypotheses are summarized in Table 4 .

Table 2 provides support for all hypotheses from 1a to 1c usingboth, Ohlson's and Grünberg's bankruptcy models. Hypothesis 1a posited that the pre-bankruptcy score values $(t-1)$ for firms failing due to a single cause would be significantly different from the score values for firms failing due to many causes. Using Ohlson's score, it can be seen in Table 2 Panel 1, that median pre-bankruptcy score for Group 1.1 firms experiencing one failure cause indicates a very healthy firm at period $t-1$ while the pre-bankruptcy score for Group 1.2 firms facing multiple causes of failure is remarkably larger, thus indicating a very unhealthy firm. The bankruptcy score medians for Groups 1.1 and 1.2 are significantly different at 0.05 p-level. Hypothesis 1a is even more strongly supported in case of Grünberg's model, namely the ISMT p-value is 0.001 . The results obtained with Ohlson's model also support hypotheses $1 \mathrm{~b}$ and $1 \mathrm{c}$. In case of Group 1.1 firms, the median $t-1$ score reflects a very healthy firm - median score value 0.05 . Also, the median of score change between periods $t-1$ and $t-2$ is minimal, thus it does not appear to indicate impending failure. On the contrary, for a median firm in Group 1.2 most of the failure occurs between $t-1$ and $t-2$, thus indicating a very unhealthy firm at $t-1$ (median score value 0.84 ). Grünberg's model also confirms hypotheses $1 \mathrm{~b}$ and $1 \mathrm{c}$. Still, despite the ISMT shows that $t-1$ median scores for the two groups differ markedly more than in case of Ohlson's model, the median value for period $t-1$ is very near to the cut-off point of 0.5 for Group 1.1 (median score value 0.49), but for Group 1.2 (median score value 0.78 ) it is quite similar to that obtained with Ohlson's model (median score value 0.84 ).

Table 2. Median bankruptcy scores and its changes by number of failure causes

Panel 1. Ohlson bankruptcy score

\begin{tabular}{lllll}
\hline Firm classification & & & & \\
by number of failure causes & $\mathrm{N}$ & Median change & Median score $_{\mathrm{t}-1}$ & Median score $_{\mathrm{t}-2}$ \\
\hline Group 1.1 Single cause & 16 & 0.01 & 0.05 & 0.02 \\
Group 1.2 Multiple causes & 54 & 0.14 & 0.84 & 0.11 \\
Total & 70 & 0.09 & 0.70 & 0.03 \\
\hline
\end{tabular}

ISMT p-value for change 0.023 , for score $t-10.023$.

Panel 2. Grünberg bankruptcy score

\begin{tabular}{lllll}
\hline $\begin{array}{l}\text { Firm classification } \\
\text { by number of failure causes }\end{array}$ & $\mathrm{N}$ & Median change & Median score $_{\mathrm{t}-1}$ & Median score $_{\mathrm{t}-2}$ \\
\hline Group 1.1 Single cause & 16 & 0.003 & 0.49 & 0.48 \\
Group 1.2 Multiple causes & 54 & 0.16 & 0.78 & 0.54 \\
Total & 70 & 0.11 & 0.68 & 0.52 \\
\hline
\end{tabular}

ISMT p-value for change 0.004 , for score $t-10.001$.

The second set of hypothesis (from 2a to 2c) focused on a taxonomy of the types of failure causes - internal, external, or both. All proposed hypotheses find support using both bankruptcy models. Hypothesis 2a predicted that the pre-bankruptcy scores of the firms failing due to one type of failure cause (Group 2.1) would not be different from the scores of firms failing due to multiple causes (Group 2.2). Panels 1 and 2 in Table 3 reveal that the medians in case of two compared groups are not significantly different for both models applied. The ISMT indicates that, in case of Ohlson's model the medians are more similar. Still, in case of Group 2.2 the median scores are slightly larger in case of both models, thus, the reasons emerging from multiple environments could 
amplify the speed of decline a bit more. Hypotheses $2 \mathrm{~b}$ and $2 \mathrm{c}$ proposed that the median scores at $t-1$ in case of firms failing due to causes from only one environment or from multiple environments both point to a bankrupting firm (i.e. the median score values are over 0.5). Hypotheses $2 \mathrm{~b}$ and $2 \mathrm{c}$ find support in case of both bankruptcy models. The bankruptcy scores for both groups (2.1 and 2.2) in case of both models point to a high bankruptcy risk (median score values over 0.75), except for the score for Group 2.1 obtained with Ohlson's model (median score value 0.63 ), which is smaller than the other scores. It should be noted that the second set of hypotheses was tested by using only those cases where there are multiple reasons present. If cases having a single failure reason (i.e. Group 1.1 cases) were included in the analysis (thus increasing the number of Group 2.1 cases in analysis), not all of the hypotheses would be accepted using both bankruptcy models. These findings appear to be logical, as the analysis of the first set of hypotheses vividly indicated that there are substantial differences in the bankruptcy scores of firms failing either because of a single or multiple causes.

Table 3. Median bankruptcy scores and its changes by types (internal/external or both) of failure causes

Panel 1. Ohlson bankruptcy score

\begin{tabular}{lllll}
\hline Firm classification by type of failure cause & $\mathrm{N}$ & Median change & Median score $_{\mathrm{t}-1}$ & Median score $_{\mathrm{t}-2}$ \\
\hline Group 2.1 One type & 20 & 0.03 & 0.63 & 0.07 \\
Group 2.2 Both types & 34 & 0.34 & 0.84 & 0.14 \\
Total & 54 & 0.14 & 0.84 & 0.11 \\
\hline
\end{tabular}

ISMT p-value for change 0.091 , for score $t-11.000$.

Panel 2. Grünberg bankruptcy score

\begin{tabular}{lllll}
\hline Firm classification by type of failure cause & $\mathrm{N}$ & Median change & Median score $_{\mathrm{t}-1}$ & Median score $_{\mathrm{t}-2}$ \\
\hline Group 2.1 One type & 20 & 0.14 & 0.76 & 0.59 \\
Group 2.2 Both types & 34 & 0.17 & 0.79 & 0.51 \\
Total & 54 & 0.16 & 0.78 & 0.54 \\
\hline
\end{tabular}

ISMT p-value for change 0.260 , for score $t-10.573$.

Note. One type - either only (multiple) internal or external causes; both types - internal and external cause(s) simultaneously present.

Table 4. Summary of the testing of hypotheses based on two bankruptcy models.

\begin{tabular}{|c|c|c|c|c|c|c|}
\hline Hypothesis & Result & $\begin{array}{l}\text { ISMT p-value for } \\
\text { Ohlson model }\end{array}$ & $\begin{array}{l}\text { ISMT p-value for } \\
\text { Grünberg model }\end{array}$ & $\begin{array}{l}\text { Ohlson's model } \\
\text { median score }\end{array}$ & $\begin{array}{l}\text { Grünberg's } \\
\text { median score }\end{array}$ & model \\
\hline 1a & $\begin{array}{l}\text { Supported in case of } \\
\text { both models }\end{array}$ & 0.023 & 0.001 & & & \\
\hline $1 b$ & $\begin{array}{l}\text { Supported in case of } \\
\text { both models }\end{array}$ & & & 0.05 & 0.49 & \\
\hline $1 \mathrm{c}$ & $\begin{array}{l}\text { Supported in case of } \\
\text { both models }\end{array}$ & & & 0.84 & 0.78 & \\
\hline $2 \mathrm{a}$ & $\begin{array}{l}\text { Supported in case of } \\
\text { both models }\end{array}$ & 1.000 & 0.573 & & & \\
\hline $2 b$ & $\begin{array}{l}\text { Supported in case of } \\
\text { both models }\end{array}$ & & & 0.63 & 0.76 & \\
\hline $2 \mathrm{c}$ & $\begin{array}{l}\text { Supported in case of } \\
\text { both models }\end{array}$ & & & 0.84 & 0.79 & \\
\hline
\end{tabular}

Note. p-value applied for ISMT 0.05 ; cut-off point for bankruptcy scores 0.5 .

In order to check the robustness of results, we conducted the following tests. First, we tested whether the size of the firms in our sample $(\mathrm{n}=70)$ is similar or different from the size of bankrupted manufacturing firms not 
included in the sample ( $\mathrm{n}=538)$. This is important because firms differing in size may experience varying failure processes (see e.g. Laitinen, 1991). We conducted an ISMT with firm turnover, total assets, and number of workers for both periods, namely $t-1$ and $t-2$, but none of the six tests showed any significant differences between the two observed groups of firms. Thus, firms not included in the current analysis do not differ with respect to size. It should also be noted that previous studies (see e.g. Hambrick \& D'Aveni, 1988; D'Aveni, 1989; Laitinen, 1991; Laitinen, 1992) have used similar sized samples as that applied in this study (i.e., below one hundred observations). In addition, we tested whether the values and changes of bankruptcy scores (both, Ohlson and Grünberg scores for periods $t-1$ and $t-2$ ) were similar for the 70 firms in our sample and the firms not included in analysis. An ISMT showed no significant differences, therefore, one can conclude that a median firm not included inthe current analysis probably experienced a process similar to that in our sample.

\section{Discussion}

This paper examined the relationship between the firm's financial decline, as indicated by bankruptcy score values and their changes, and the number and types of causes of firm failure. Although the creation of bankruptcy models has been very thoroughly studied in the past few decades, the relationship between bankruptcy scores and the causes of failure has not received attention in the literature. Another challenge in this study was determining the selection of bankruptcy prediction models suitable for use in a specific business environment. The causes of business failure have also received little attention and, therefore, only a few systematic studies can be found focusing on the topic. A few thorough empirical studies have sought to link the causes of failure with the failure process reflected through financial indicators, but none of these studies have specifically examined the connection between failure causes and changes in the firm's financial health as reflected by bankruptcy models. Thus, this study helps to establish the relationship between both the number and types of failure causes and the changes in the firm's financial health.

Empirical data on failure causes were extracted from Estonian county court judgments. In addition, bankruptcy score values using two models, a most-cited logit model by Ohlson (1980) and a local logit model by Grünberg and Lukason (2014) were calculated for two points of time (one year and two years prior to bankruptcy). In total, 70 cases were applicable for the current study. The results indicate that firms failing due to a single reason (which is either internal or external to firm), show little change in their bankruptcy model score during the year prior to the declaration of bankruptcy. Moreover, their financial health as reflected by the same score appears to be very good. On the contrary, companies experiencing multiple causes have a significantly larger change in their bankruptcy score during the pre-bankruptcy year, and the median score indicates a very high risk of bankruptcy. These results provide very interesting insights in the light of available literature. Namely, the sudden decliners described by D'Aveni (1989) and the acute failure firms in Laitinen's (1991) study, which are characteristic of a rapid decline just before failure, tend to be associated with a single cause of failure. Such a cause commonly represents a severe environmental shock or mismanagement of the firm. On the contrary, for firms witnessing several failure causes, the decline starts earlier and at the end of the pre-bankruptcy year, the firm can be considered bankrupt or in very poor financial health. Thus, it appears that the gradual decliners noted by D'Aveni (1989) and Laitinen's (1991) revenue financing firms are associated with multiple failure causes.

The comparison of the impact of the types of failure causes - from only one environment (either internal or external) or from both environments - on the bankruptcy score and its change over time also yielded interesting results. Namely, the bankruptcy scores of firms witnessing either multiple reasons from a single or different environment are not significantly different in the pre-bankruptcy year. Also, for both given groups of firms both bankruptcy models indicate a firm in poor financial health. These findings are also interesting in the light of available literature. Namely, firms with multiple internal deficiencies (for instance, too high fixed costs and insufficient quality of products) decline in the same manner as those experiencing deficiencies from both types of failure causes (for instance poor financial planning and growth in competition). This finding enriches the resource-based view context of firm failure (see e.g. Thornhill \& Amit, 2003), namely that firms operating in a changing environment can fail similarly to those in an unchanging environment.

This study integrates some of the available literature by demonstrating that suddenly failing firms as described by both D'Aveni (1989) and Laitinen (1991) are characterized by a failure cause from a single environment either internal or external to the firm (e.g. Boyle \& Desai, 1991); whereas, for gradually declining firms described in the aforementioned studies, failure stems from both internal and external causes. Thus, a major contribution of this study is that some possible reasons for a gradual or rapid process of decline have been identified. That is the number of causes of failure is important. At this point we can only say that the types of causes of failure may also be important, but their effects on the process are not as strong. This study represents a particularly good test of these relationships for two reasons. First, the use of manufacturing firms is a good 
sample to examine the types of failure causes because these firms have more complex processes than say service or the retailing sector firms, permitting greater variability in failure causes. In addition, the manufacturing sector was less affected by the economic downturn that occurred during the data collection period. Thus, the causes of failure for these firms are not necessarily associated with the economic effects of the period of observation.

The study has several limitations that could be relaxed in future research. First, the analysis would benefit from a larger sample. Second, monthly financial data and the exact time period when the causes of failure emerge would shed more light on the failure process. Third, the availability of firm level data from trustees would also enable researchers to account for the specific impact of each failure cause. Finally, a more detailed taxonomy of failure causes needs to be developed to better determine the effects of different types of failure causes on the process of business decline.

There are several stakeholders who can benefit from the results of this study. First, creditors applying bankruptcy models can adjust their managerial decisions based on bankruptcy models if they become aware of the number and type of causes (internal or external) that might be associated with a drop in bankruptcy score value. Furthermore, creditors and other stakeholders can assume that a certain proportion of failure cases are not predictable through financial indicators, and therefore, they would benefit from using other measures to forecast a firm's forthcoming failure. Policy makers can make use of the knowledge that small manufacturing firm failure is overwhelmingly caused by multiple failure reasons which in turn mostly emerges from factors both internal and external to the firm. Thus, poor managerial skills or unfavorable environmental developments alone normally may not lead to the rapid collapse of the firm.

\section{Acknowledgments}

Oliver Lukason acknowledges financial support from Estonian Research Council grant IUT20-49 "Structural Change as the Factor of Productivity Growth in the Case of Catching up Economies" and Estonian Science Foundation grant number ETF8546 "Internationalization processes: a typology, frequency and impact factors". Richard Hoffman acknowledges financial support from Fulbright Grant, USA.

\section{References}

Altman, E. I., \& Narayanan, P. (1997). An international survey of business failure classification models. Financial markets, Institutions \& Instruments, 6(2), 1-57. http://dx.doi.org/10.1111/1468-0416.00010

Argenti, J. (1976). Corporate collapse: the causes and symptoms. New York: McGraw-Hill.

Baldwin, J., Gray, T., Johnson, J., Proctor, J., Raffiquzamann, M., \& Sabourin, D. (1997). Failing concerns: business bankruptcy in Canada. Ottawa: Analytical Studies Branch of Statistics Canada.

Barker III, V. L., \& Duhaime, I. M. (1997). Strategic change in the turnaround process: theory and empirical evidence. Strategic Management Journal, $18(1), \quad 13-38$. http://dx.doi.org/10.1002/(SICI)1097-0266(199701)18:1<13::AID-SMJ843>3.0.CO;2-X

Beaver, G. (2003). Small business: success and failure. Strategic Change, 12(3), 115-122. http://dx.doi.org/10.1002/jsc.624

Bibeault, D. B. (1982). Corporate turnaround: how managers turn losers into winners. New York: McGraw-Hill.

Blazy, R., \& Chopard, B. (2012). (Un)secured debt and the likelihood of court-supervised reorganization. European Journal of Law and Economics, 34(1), 45-61. http://dx.doi.org/10.1007/s10657-010-9160-4

Boyle, R. D., \& Desai, H. B. (1991). Turnaround strategies for small firms. Journal of Small Business Management, 29(3), 33-42.

Cochran, A. B. (1981). Small business mortality rates: a review of the literature. Journal of Small Business Management, 19(4), 50-59.

Constand, R. L., \& Yazdipour, R. (2011). Firm failure prediction models: a critique and a review of recent developments. In R. Yazdipour (Ed.), Advances in Entrepreneurial Finance: With Applications from Behavioral Finance and Economics (pp. 185-204). New York: Springer. http://dx.doi.org/10.1007/978-1-4419-7527-0_10

Crutzen, N. (2009). Essays on the prevention of small business failure: taxonomy and validation of five explanatory business failure patterns (Unpublished doctoral dissertation). University of Liege, Belgium.

D'Aveni, R. A. (1989). The aftermath of organizational decline: a longitudinal study of the strategic and managerial characteristics of declining firms. Academy of Management Journal, 32(3), 577-605. 
http://dx.doi.org/10.2307/256435

Dimitras, A. I., Zanakis, S. H., \& Zopounidis, C. (1996). A survey of business failures with an emphasis on prediction methods and industrial applications. European Journal of Operational Research, 90(6), 487-513. http://dx.doi.org/10.1016/0377-2217(95)00070-4

Dubrovski, D. (2009). Management mistakes as causes of corporate crisis: managerial implications for countries in transition. Total Quality Management, 20(1), 39-59. http://dx.doi.org/10.1080/14783360802614281

Fredland, J. E., \& Morris, C. E. (1976). A cross section analysis of small business failure. American Journal of Small Business, 1(1), 7-18.

Gaskill, L. A. R., Manning, R. A., \& Van Auken, H. E. (1993). A factor analytic study of the perceived causes of small business failure. Journal of Small Business Management, 31(4), 18-31.

Grünberg, M., \& Lukason, O. (2014). Predicting bankruptcy of manufacturing firms. International Journal of Trade, Economics and Finance, 5(1), 93-97. http://dx.doi.org/10.7763/IJTEF.2014.V5.347

Hall, G. (1992). Reasons for insolvency amongst small firms - a review and fresh evidence. Small Business Economics, 4(3), 237-250.

Hambrick, D. C., \& D’Aveni, R. (1988). Large corporate failures as downward spirals. Administrative Science Quarterly, 33(1), 1-23. http://dx.doi.org/10.2307/2392853

Laitinen, E. K. (1991). Financial ratios and different failure processes. Journal of Business Finance \& Accounting, 18(5), 649-673. http://dx.doi.org/10.1111/j.1468-5957.1991.tb00231.x

Laitinen, E. K. (1992). Prediction of failure of a newly founded firm. Journal of Business Venturing, 7(4), 323-340. http://dx.doi.org/10.1016/0883-9026(92)90005-C

Laitinen, E. K. (1993). Financial predictors for different phases of firm failure. Omega, 21(2), 215-228. http://dx.doi.org/10.1016/0305-0483(93)90054-O

Laitinen, E. K., \& Lukason, O. (2014). Do firm failure processes differ across countries: evidence from Finland and Estonia. Journal of Business Economics and Management (forthcoming). http://dx.doi.org/10.3846/16111699.2013.791635

Lukason, O. (2013). Firm bankruptcies and violations of law: an analysis of different offences. In T. Vissak, \& M. Vadi (Eds.), Dishonesty in Management: Manifestations and Consequences (pp. 127-146). Bingley: Emerald. http://dx.doi.org/10.1108/S1877-6361(2013)0000010010

Mellahi, K., \& Wilkinson, A. (2004). Organizational failure: a critique of recent research and a proposed integrative framework. International Journal of Management Reviews, 5(1), 21-41. http://dx.doi.org/10.1111/j.1460-8545.2004.00095.x

Moulton, W. N., Thomas, H., \& Pruett, M. (1996). Business failure pathways: environmental stress and organizational response. Journal of Management, 22(4), 571-593. http://dx.doi.org/10.1177/014920639602200403

Ohlson, J. A. (1980). Financial ratios and the probabilistic prediction of bankruptcy. Journal of Accounting Research, 18(1), 109-131. http://dx.doi.org/10.2307/2490395

Ooghe, H., \& Balcaen, S. (2007). Are failure prediction models widely usable? An empirical study using a Belgian dataset. Multinational Finance Journal, 11(1/2), 33-76.

Ooghe, H., \& De Prijcker, S. (2008). Failure processes and causes of company bankruptcy: a typology. Management Decision, 46(2), 223-242. http://dx.doi.org/10.1108/00251740810854131

Pretorius, M. (2009). Defining business decline, failure and turnaround: a content analysis. Southern African Journal of Entrepreneurship and Small Business Management, 2(1), 1-16.

Robbins, D. K., \& Pearce II, J. A. (1992). Turnaround: retrenchment and recovery. Strategic Management Journal, 13(4), 287-309. http://dx.doi.org/10.1002/smj.4250130404

Thornhill, S., \& Amit, S. (2003). Learning About Failure: Bankruptcy, Firm Age, and the Resource-Based View. Organization Science, 14(5), 497-509. http://dx.doi.org/10.1287/orsc.14.5.497.16761

Trahms, C. A., Ndofor, H. A., \& Sirmon, D. G. (2013). Organizational decline and turnaround: a review and agenda for future research. Journal of Management, 39(5), 1277-1307. http://dx.doi.org/10.1177/0149206312471390 
Van Witteloostuijn, A. (1998). Bridging behavioral and economic theories of decline: organizational inertia, strategic competition, and chronic failure. Management Science, 44(4), 501-519. http://dx.doi.org/10.1287/mnsc.44.4.501

Weitzel, W., \& Jonsson, E. (1989). Decline in organizations: a literature integration and extension. Administrative Science Quarterly, 34(1), 91-109. http://dx.doi.org/10.2307/2392987

\section{Appendix}

Appendix A. Different bankruptcy reasons brought out by trustees in the court judgments used in current study

Internal (33 different)
Incompetence of management, management faults, irrational business decisions, not correct management action,
management fraud, production of insufficient quality good, too high fixed costs, poor business plan, lack of cash for
operations, poor financial planning, no control over costs, poor knowledge of market, high costs, funding investment with
short-term loans, incapability to find additional financing, too high self-price, disagreements in management board, too
low equity, failed investments, problems in arranging activities and book keeping, insufficient knowledge to act in crisis,
increase in costs when turnover increases, not knowing market, failed projects, deficiencies in price calculation,
economically irrational activities, too large debt burden, inability to collect debt, incapability to adjust to changed
economic conditions, dependence from a few customers, unprofessional workers, inefficient equipment, too exclusive
product

External (28 different)

Bad climate conditions, changes in foreign exchange rates, tax dispute, market recession, growth in competition, growth in low price goods from Asia, low quality input material, growth in input material price, changes in laws, lack of skilled workforce, death of manager, leaving of major clients, fire in production facility, theft of machinery, bankruptcy of major customer, sales manager left with major clients, termination of supply due to supplier bankruptcy, new owners of partner are not cooperative, bank quit factoring, unstable orders, bankruptcy of firm connected with member of board, payment defaults of clients, ill health of manager, impossible to compromise with government agency, lack of interest in buyers, economic crisis, general growth in workforce cost, lack of financiers at market

Appendix B. Variables and coefficients of Ohlson's third logit bankruptcy model based on the data of US manufacturing firms from year 1980

\begin{tabular}{ll}
\hline Variable & Coefficient \\
\hline Constant & 1.13 \\
SIZE measured by log(total assets / GNP price-level) & -0.478 \\
TLTA measured by total liabilities to total assets & 5.29 \\
WCTA measured by working capital to total assets & -0.990 \\
CLCA measured by current liabilities to current assets & 0.062 \\
OENEG having value one if total liabilities exceed total assets and zero otherwise & -1.91 \\
NITA measured by net income to total assets & -4.62 \\
FUTL measured by funds provided by operations to total liabilities & -2.25 \\
INTWO having value one if net income was negative for the last two years and zero otherwise & -0.521 \\
CHIN measured by $\left(\mathrm{NI}_{\mathrm{t}}-\mathrm{NI}_{\mathrm{t}-1}\right) /\left(\left|\mathrm{NI}_{\mathrm{t}}\right|+\left|\mathrm{NI}_{\mathrm{t}-1}\right|\right)$ & 0.212 \\
\hline
\end{tabular}

Note. $\mathrm{p}=1$ firm is bankrupt, $\mathrm{p}=0$ firm is not bankrupt. Source: Ohlson 1980 .

Appendix C. Variables and coefficients of Grünberg's logit bankruptcy model based on the data of Estonian manufacturing firms

\begin{tabular}{ll}
\cline { 2 - 2 } Variable & Coefficient \\
\hline Constant & -0.920 \\
Capital structure (equity / total assets) & -1.815 \\
Asset structure (current assets / total assets) & 0.869 \\
Size (natural logarithm of operating revenue) & 0.046 \\
\hline
\end{tabular}

Note. $\mathrm{p}=1$ firm is bankrupt, $\mathrm{p}=0$ firm is not bankrupt. Source: Grünberg and Lukason 2014. 


\section{Copyrights}

Copyright for this article is retained by the author(s), with first publication rights granted to the journal.

This is an open-access article distributed under the terms and conditions of the Creative Commons Attribution license (http://creativecommons.org/licenses/by/3.0/). 